\title{
(2) OPEN ACCESS \\ Child mortality in England during the first year of the COVID-19 pandemic
}

\author{
David Odd ${ }^{1,2}$ Sylvia Stoianova, ${ }^{2}$ Tom Williams, ${ }^{2}$ Peter Fleming (1) , 2,3 Karen Luyt (1) 2,3
}

${ }^{1}$ Population Medicine, Cardiff University, Cardiff, UK

${ }^{2}$ National Child Mortality Database, University of Bristol, Bristol, UK

${ }^{3}$ Centre for Academic Child Health, University of Bristol, Bristol, UK

\section{Correspondence to}

Dr Karen Luyt, Translational Health Sciences, University of Bristol Medical School, Bristol BS8 1TH, UK:

karen.luyt@bristol.ac.uk

Received 12 October 2021 Accepted 12 November 2021

D) Check for updates

(c) Author(s) (or their employer(s)) 2021. Re-use permitted under CC BY-NC. No commercial re-use. See rights and permissions. Published by BMJ.

To cite: Odd D, Stoianova S, Williams T, et al.

Arch Dis Child Epub ahead of print: [please include Day

Month Year]. doi:10.1136/

archdischild-2021-323370

\section{ABSTRACT}

Objectives To quantify the relative risk (RR) of childhood deaths across the whole of England during the first year of the COVID-19 pandemic, compared with a similar period of 2019.

Design This work is based on data collected by the National Child Mortality Database (NCMD). Deaths from 1 April 2020 until 31 March 2021 (2020-2021) were compared with those from the same period of 2019 2020. RR and excess mortality were derived for deaths in 2020-2021 vs 2019-2020.

Setting All deaths reported to NCMD in England of children under 18 years of age, between April 2019 and March 2021.

Participants 6490 deaths of children, under the age of 18 years, reported to the NCMD over the study period.

Results Children had similar demographics in the 2 years. There were 356 (198-514) fewer deaths in 2020-2021 than in 2019-2020 (RR 0.90 (0.85 to $0.94), p<0.001)$. Deaths from infection (RR 0.49 (0.38 to 0.64$))$ and from other underlying medical conditions (RR 0.75 (0.68 to 0.82)) were lower in 2020-2021 than 2019-2020, and weak evidence (RR 0.50 (0.23 to 1.07), $p=0.074$ ) that this was also true of deaths from substance abuse.

Conclusions Childhood mortality in England during the first year of the SARS-CoV-2 pandemic was lower than expected, with over 300 fewer deaths than the preceding 12 months. The greatest reduction was in children less than 10 years old. It is important that we learn from this effect that potentially offers alternative ways to improve the outcome for the most vulnerable children in our society.

\section{BACKGROUND}

In England, the Office for National Statistics (ONS) published data suggesting an increase in the total population mortality of $14 \%$ for 2020 compared with previous years. ${ }^{1}$ While the direct impact of COVID-19 is significant, the widespread changes in healthcare and society over the year are also likely to have had broad impacts on access to healthcare and the risks of infections. The COVID-19 pandemic also comes at a time with England reporting its lowest levels of infant mortality on record ${ }^{2}$; and as the pandemic progressed, children appeared to be one of the age groups least affected by the virus, ${ }^{3}$ but potentially most effected by the social changes put in place: with the closure of schools, specific concerns over their mental health ${ }^{4-6}$ and the delivery of antenatal care. ${ }^{8}$ Consequently, the overall impact of COVID-19 on childhood mortality is unclear. ${ }^{9}$ While some children have died

\section{What is already known on this topic?}

In England, overall mortality during 2020 was $14 \%$ higher than the previous year.

- The direct impact of COVID-19 in children is relatively small, but widespread changes in healthcare are likely to have had broad impacts on child health.

\section{What this study adds?}

- There was an unexpected fall in overall child mortality in England, most marked in younger children and those with underlying health conditions.

- It is important that we learn from this effect that potentially offers alternative ways to improve the outcome for the most vulnerable children in our society.

as a direct consequence of COVID-19, concerns remain that others may have suffered due to social restrictions, ${ }^{10-12}$ with specific concerns over those already at higher risk due to medical problems or in difficult socioeconomic environments. ${ }^{13}$ The overall excess mortality for children is unknown, and while initial estimates have suggested an overall reduction in child mortality across England, ${ }^{14}$ identifying which children were most affected, whether this affects all demographic groups and how this relates to the lockdown measures, needs clarifying.

In England, all children have their deaths reviewed by a specialist service, the Child Death Overview Panels (CDOPs); and from 1 April 2019, the National Child Mortality Database (NCMD) was formed to collate data on all children who die in England before their 18th birthday, with death notifications required by statute within 48 hours. ${ }^{15}$ The aim of this analysis was to quantify the relative risk (RR) of childhood deaths, across the whole of England during the first year of the COVID-19 pandemic, compared with the previous year.

\section{METHODS}

The NCMD commenced data collection on 1 April 2019 and collects data from all 58 CDOPs across England. ${ }^{16}$ All deaths of children in England will ultimately be reviewed in depth by the CDOPs, but this process often takes many months. In this work, similar to our previous work, ${ }^{14}$ to obtain a provisional category of death, all child deaths reported to the NCMD were coded contemporaneously by the 


\begin{tabular}{|c|c|c|c|c|}
\hline Measure & $\begin{array}{l}\text { Number } \\
\text { with data }\end{array}$ & $2019(n=3423)$ & $2020(n=3067)$ & $P$ value \\
\hline \multicolumn{5}{|l|}{ Age } \\
\hline $\begin{array}{l}\text { Median (IQR) } \\
\text { (years) }\end{array}$ & 6490 & $0.2(0.0-5.3)$ & $0.1(0.0-6.2)$ & 0.215 \\
\hline Sex & 6354 & & & 0.939 \\
\hline Female & & 1466 (43.5\%) & 1304 (43.7\%) & \\
\hline Male & & 1901 (56.5\%) & $1683(56.3 \%)$ & \\
\hline Ethnic group & 5597 & & & 0.155 \\
\hline $\begin{array}{l}\text { Asian or Asian } \\
\text { British }\end{array}$ & & $557(18.9 \%)$ & 462 (17.4\%) & \\
\hline $\begin{array}{l}\text { Black or black } \\
\text { British }\end{array}$ & & $252(8.6 \%)$ & 247 (9.3\%) & \\
\hline Mixed & & $188(6.4 \%)$ & $156(5.9 \%)$ & \\
\hline Other & & $94(3.2 \%)$ & 65 (2.5\%) & \\
\hline White & & $1855(63.0 \%)$ & 1721 (64.9\%) & \\
\hline $\begin{array}{l}\text { Deprivation } \\
\text { measure }(1-10)^{19}\end{array}$ & 6339 & $4(2-7)$ & $4(2-7)$ & 0.904 \\
\hline Region & 6490 & & & 0.885 \\
\hline East Midlands & & $283(8.3 \%)$ & $251(8.2 \%)$ & \\
\hline East of England & & $339(9.9 \%)$ & $278(9.1 \%)$ & \\
\hline London & & $609(17.8 \%)$ & $563(18.4 \%)$ & \\
\hline North East & & $154(4.5 \%)$ & $138(4.5 \%)$ & \\
\hline North West & & $500(14.6 \%)$ & $431(14.1 \%)$ & \\
\hline South East & & $468(13.7 \%)$ & $403(13.1 \%)$ & \\
\hline South West & & $252(7.4 \%)$ & $235(7.7 \%)$ & \\
\hline West Midlands & & $451(13.2 \%)$ & $436(14.2 \%)$ & \\
\hline $\begin{array}{l}\text { Yorkshire and } \\
\text { Humber }\end{array}$ & & $367(10.7 \%)$ & $332(10.8 \%)$ & \\
\hline Place of death & 6362 & & & $<0.001$ \\
\hline Abroad & & $10(0.3 \%)$ & $25(0.8 \%)$ & \\
\hline Home & & $428(12.7 \%)$ & $531(17.7 \%)$ & \\
\hline Hospice & & $145(4.3 \%)$ & $117(3.9 \%)$ & \\
\hline Hospital & & $2615(77.8 \%)$ & $2193(73.1 \%)$ & \\
\hline Other & & $165(4.9 \%)$ & $133(4.4 \%)$ & \\
\hline
\end{tabular}

Numbers are $\mathrm{n}(\%)$ or median (IQR) as appropriate.

Comparisons were made using Fisher's exact test or Mann-Whitney U test as appropriate.

same three independent coders (all paediatricians (DO, PF, KL)) to identify the most likely category of the cause of death. ${ }^{17}$ All coders recorded a provisional category of death (see below) or that there was insufficient information provided. For each death, if two or more coders agreed on a category, this was taken as the most likely category; and where no two coders agreed, the category highest in the following hierarchy was used (based on categorisation used by CDOPs). ${ }^{18}$

1. Suicide.

2. Substance abuse.

3. Trauma (subcategorised to those deaths due to road traffic accidents, drownings and 'other').

4. Malignancy.

5. Underlying medical condition.

6. Intrapartum event.

7. Preterm birth.

8. Infection.

9. Sudden unexpected deaths in infancy or childhood (SUDIC).
In addition, the CDOPs also report baseline characteristics of the child, from which the following data were derived from the notification form:

- Sex of individual (female, male, other (including not known)).

- Ethnic group (Asian or Asian British, black or black British, mixed, other, unknown, white).

- Age at death.

- The region where the death was reported from.

- From the child's home postcode, the Index of Multiple Deprivation (IMD), a measure of local deprivation ${ }^{19}$ (on a score of 1-10) with a lower value suggesting greater deprivation.

From 1 March 2020, linkage with virology PCR results was performed with Public Health England; and from April 2020, the Joint Agency Response to unexpected child deaths during the COVID-19 pandemic protocol was amended to include postmortem viral swabs from all children dying with no immediately identifiable cause. $^{20}$

\section{Statistical analysis}

Deaths of children occurring from 1 April 2020 until 31 March 2021 (2020-2021) were compared with those from the same period of 2019-2020. Initially, we compared the characteristics of those children who died in 2020-2021 vs 2019-2020. Comparisons were made using Fisher's exact test for categorical data, and Mann-Whitney U test for age and the IMD category. Next, using the total number of deaths over the 2 years, the number of excess deaths in 2020-2021 was calculated using the 2019-2020 data. In addition, the RR of deaths between the 2 years was compared using a Negative Binomial Regression model, ${ }^{6}$ chosen to remain consistent with other work within the cohort. The population of interest was for all deaths of children, including neonatal deaths, before their 18th birthday. Overall population size was assumed to be 12023568 (the ONS 2019 midyear population estimate). ${ }^{21}$ This model was then repeated with the deaths stratified by month of death, and then by demographics of the population: age of death, ethnic group, sex, region of the country and deprivation score (the ONS IMD ${ }^{19}$ ). Models were repeated with the risk calculated for each category, and overall $\mathrm{p}$ values derived to test if the risk of death and year were modified by the characteristic being tested. Population profile was obtained from the 2019 ONS population estimates ${ }^{21}$ for all measures except ethnicity, which was based on the 2011 census data. ${ }^{22}$ Absolute numbers of deaths and excess mortality for 2020-2021 vs 2019-2020 (with CIs) were also calculated from the frequencies seen. Finally, we repeated the main model restricting it to each provisional category of death.

Data are presented as median (IQR), number (\%), absolute difference $(95 \% \mathrm{CI})$ or $\mathrm{RR}$ ratio $(95 \% \mathrm{CI})$. Where frequency counts were below 5 , or could be derived, absolute numbers are not presented. Analysis was performed using Stata V.16. Existing parent and public involvement representation supported the project throughout (see the Acknowledgements section).

\section{RESULTS}

Data were downloaded from the NCMD system on 7 June 2021. Between April 2019 and March 2020 (inclusive), there were 3423 deaths of children, under the age of 18 years, reported to the NCMD. For the corresponding period from April 2020, this had dropped to 3067. Children who died between April 2020 and March 2021 had similar median ages $(p=0.215)$, sex distribution $(p=0.939)$, median deprivation scores $(p=0.904)$ 
Table 2 Relative risk (RR) of death by calendar month, age, sex, deprivation, region and ethnicity; with estimates of RR between years and the number of excess deaths calculated

\begin{tabular}{|c|c|c|c|c|c|c|}
\hline \multirow[b]{2}{*}{ Measure } & \multicolumn{5}{|c|}{ Comparison of deaths between 2019 and 2020 (April-March) } & \multirow[b]{2}{*}{$\mathbf{p}_{\text {interaction }}$} \\
\hline & 2019 & 2020 & Excess deaths & RR & $P$ value & \\
\hline All deaths & 3423 & 3067 & $-356(-514$ to -198$)$ & 0.90 (0.85 to 0.94$)$ & $<0.001$ & \\
\hline Stratified by month of death & & & & & & 0.181 \\
\hline April & 262 & 268 & $6(-39$ to 51$)$ & 1.02 (0.86 to 1.21$)$ & 0.794 & \\
\hline May & 270 & 269 & $-1(-47$ to 45$)$ & $1.00(0.84$ to 1.18$)$ & 0.966 & \\
\hline June & 238 & 234 & $-4(-47$ to 39$)$ & $0.98(0.82$ to 1.18$)$ & 0.854 & \\
\hline July & 261 & 263 & $2(-43$ to 47$)$ & 1.01 (0.85 to 1.20$)$ & 0.930 & \\
\hline August & 308 & 263 & $-45(-92$ to 2$)$ & 0.85 (0.72 to 1.01$)$ & 0.060 & \\
\hline September & 275 & 245 & $-30(-75$ to 15$)$ & 0.89 (0.75 to 1.06$)$ & 0.189 & \\
\hline October & 294 & 221 & $-73(-117$ to -29$)$ & $0.75(0.63$ to 0.90$)$ & 0.001 & \\
\hline November & 318 & 245 & $-73(-120$ to -26$)$ & 0.77 (0.65 to 0.91$)$ & 0.002 & \\
\hline December & 333 & 267 & $-66(-114$ to -18$)$ & 0.80 (0.68 to 0.94$)$ & 0.007 & \\
\hline January & 315 & 283 & $-32(-80$ to 16$)$ & 0.90 (0.77 to 1.05$)$ & 0.191 & \\
\hline February & 256 & 237 & $-19(-63$ to 25$)$ & $0.93(0.78$ to 1.10$)$ & 0.392 & \\
\hline March & 293 & 272 & -21 (-68 to 26$)$ & 0.93 (0.79 to 1.09 ) & 0.377 & \\
\hline Stratified by age & & & & & & $<0.001$ \\
\hline Less than 1 year & 2155 & 1993 & $-162(-288$ to -36$)$ & 0.92 (0.87 to 0.98 ) & 0.012 & \\
\hline $1-4$ years & 394 & 264 & $-130(-180$ to -80$)$ & 0.67 (0.57 to 0.78$)$ & $<0.001$ & \\
\hline $5-9$ years & 243 & 197 & $-46(-87$ to -5$)$ & 0.81 (0.67 to 0.98 ) & 0.029 & \\
\hline $10-14$ years & 289 & 274 & $-15(-62$ to 32$)$ & 0.95 (0.80 to 1.12$)$ & 0.527 & \\
\hline 15-17 years & 342 & 339 & $-3(-54$ to 48$)$ & 0.99 (0.85 to 1.15$)$ & 0.908 & \\
\hline Stratified by sex & & & & & & 0.926 \\
\hline Male & 1901 & 1683 & $-218(-335$ to -101$)$ & 0.89 (0.83 to 0.95$)$ & $<0.001$ & \\
\hline Female & 1466 & 1304 & $-162(-265$ to -59$)$ & $0.89(0.83$ to 0.96$)$ & 0.002 & \\
\hline Stratified by deprivation measure* & & & & & & 0.912 \\
\hline $1 / 2$ & 1134 & 1012 & $-122(-213$ to -31$)$ & 0.89 (0.82 to 0.97$)$ & 0.008 & \\
\hline $3 / 4$ & 764 & 692 & $-72(-147$ to 3$)$ & $0.91(0.82$ to 1.00$)$ & 0.059 & \\
\hline $5 / 6$ & 616 & 529 & $-87(-153$ to -21$)$ & 0.86 (0.76 to 0.96$)$ & 0.010 & \\
\hline $7 / 8$ & 476 & 413 & $-63(-121$ to -5$)$ & 0.87 (0.76 to 0.99$)$ & 0.035 & \\
\hline $9 / 10$ & 364 & 339 & $-25(-77$ to 27$)$ & $0.93(0.80$ to 1.08$)$ & 0.346 & \\
\hline Stratified by region & & & & & & 0.885 \\
\hline East Midlands & 283 & 251 & $-32(-77$ to 13$)$ & $0.89(0.75$ to 1.05$)$ & 0.166 & \\
\hline East of England & 339 & 278 & $-61(-110$ to -12$)$ & $0.82(0.70$ to 0.96$)$ & 0.014 & \\
\hline London & 609 & 563 & $-46(-113$ to 21$)$ & $0.92(0.82$ to 1.04$)$ & 0.179 & \\
\hline North East & 154 & 138 & $-16(-49$ to 17$)$ & 0.90 (0.71 to 1.13$)$ & 0.349 & \\
\hline North West & 500 & 431 & $-69(-129$ to -9$)$ & 0.86 (0.76 to 0.98$)$ & 0.024 & \\
\hline South East & 468 & 403 & $-65(-123$ to -7$)$ & 0.86 (0.75 to 0.98$)$ & 0.028 & \\
\hline South West & 252 & 235 & $-17(-60$ to 26$)$ & 0.93 (0.78 to 1.11$)$ & 0.441 & \\
\hline West Midlands & 451 & 436 & $-15(-73$ to 43$)$ & $0.97(0.85$ to 1.10$)$ & 0.615 & \\
\hline Yorkshire and Humber & 367 & 332 & $-35(-87$ to 17$)$ & 0.90 (0.78 to 1.05$)$ & 0.186 & \\
\hline Stratified by ethnic group & & & & & & 0.153 \\
\hline Asian or Asian British & 557 & 462 & $-95(-158$ to -32$)$ & 0.83 (0.73 to 0.94$)$ & 0.003 & \\
\hline Black or black British & 252 & 247 & -5 (-49 to 39$)$ & 0.98 (0.82 to 1.17$)$ & 0.823 & \\
\hline Mixed & 188 & 156 & $-32(-68$ to 4$)$ & $0.83(0.67$ to 1.03$)$ & 0.085 & \\
\hline Other & 94 & 65 & $-29(-54$ to -4$)$ & 0.69 (0.50 to 0.95$)$ & 0.022 & \\
\hline White & 1855 & 1721 & $-134(-251$ to -17$)$ & 0.93 (0.87 to 0.99$)$ & 0.025 & \\
\hline
\end{tabular}

Numbers are frequency counts or RR plus $95 \% \mathrm{Cl}$ as appropriate.

RR derived from Negative Binomial Model (all alpha values approximating to 0 ).

Bolded rows represent periods of national lockdown.

Some demographic data missing, so denominators may vary between analyses.

* Level one is most deprived area, 10 is least deprived.

and ethnic groups $(\mathrm{p}=0.155)$ to those who died in 2019-2020 (table 1). However, the place of death did appear to be different $(\mathrm{p}<0.001)$, with more children dying at home (531 $(17.7 \%)$ vs $428(12.7 \%))$ in 2020-2021 than 2019-2020. A total of 70 children died following a positive SARS-CoV-2 test at any time, with 3 in March 2020 and 67 in the subsequent 12 months.

Overall, there were 356 (198-514) fewer deaths in 20202021 than in $2019-2020$ (RR 0.90 (0.85 to 0.94$), p<0.001$ ) 


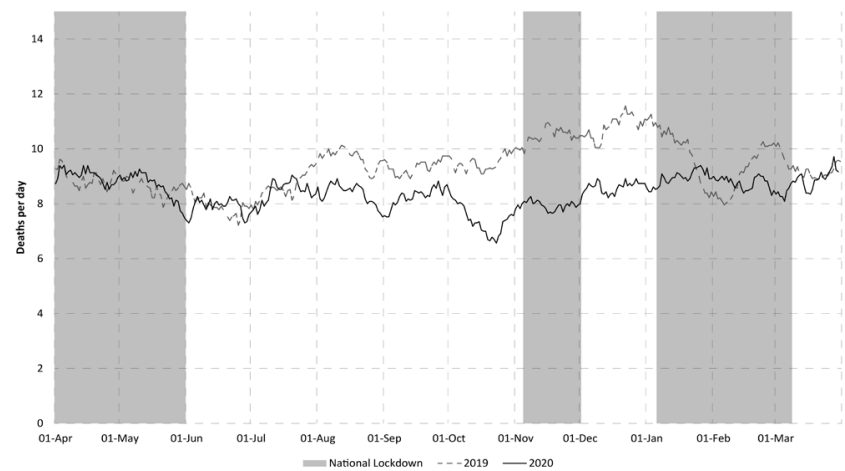

Figure 1 Mean number of deaths per day (21-day smoothed (arithmetic) average) by time period. Periods of national lockdown shaded.

(table 2). There was evidence that the reduction in deaths was different by age $(p<0.001)$, but no evidence that this reduction was significantly modified by month of death $(p=0.181)$, sex $(p=0.926)$, deprivation score $(p=0.912)$, region $(p=0.885)$ or ethnicity $(\mathrm{p}=0.153)$. When stratifying by month, fewer deaths appeared to occur in 2020-2021 than 2019-2020, in October (RR 0.75 (0.63 to 0.90)), November (RR 0.77 (0.65 to 0.91)) and December (RR 0.80 (0.68 to 0.94)) (figure 1$)$. When stratifying by age of death, fewer deaths of children below 10 years occurred in 2020-2021 than 2019-2020 (infants under 1 year, RR 0.92 (0.87 to 0.98 ); 1-4 years, RR 0.67 (0.57 to 0.78 ); and 5-9 years, RR 0.81 ( 0.67 to 0.98$)$ ), but for older children there was no significant reduction in number of deaths (10-14 years, RR 0.95 (0.80 to 1.12$)$; $15-17$ years, RR 0.99 (0.85 to 1.15$)$ ). When stratifying by deprivation, deaths were lower in 20202021 for all categories except the least deprived (RR 0.93 (0.80 to 1.08$)$ ) although there was limited evidence for interaction overall. Similarly, when stratifying deaths by ethnicity, there was some evidence of a reduction in mortality for all groups except black or black British children (RR 0.98 (0.82 to 1.17)), but only limited evidence $(p=0.1534)$ for an overall interaction. There was little change in the RRs between males and females.
Finally, repeating the analysis by category of death showed that deaths categorised as infection (RR 0.49 (0.38 to 0.64$)$ ) and from other underlying medical conditions (RR $0.75(0.68$ to 0.82)) were lower in 2020-2021 than 2019-2020, and there was weak evidence $(p=0.074)$ that this was also true of deaths from substance abuse (table 3 ). Mortality from malignancy $(\mathrm{p}=0.861)$, preterm birth $(\mathrm{p}=0.619)$, intrapartum events $(p=0.186)$, trauma $(p=0.102)$, suicide $(p=0.467)$ and SUDIC $(p=0.583)$ was similar between the 2 years. Overall, there was strong evidence that the profile of deaths differed between the 2 years $(\mathrm{p}<0.001)$.

\section{DISCUSSION}

Childhood mortality In England during the profound healthcare and social changes implemented during the first year of the SARS-CoV-2 pandemic was lower than the preceding year, with over 300 fewer deaths than expected. The reduction in overall mortality was most marked in children less than 10 years of age and appeared due to fewer deaths from infections (other than SARS-CoV-2), and fewer deaths of children from underlying conditions. In addition, the reduction in mortality appeared to occur during the winter months, where the seasonal increase, often caused by pathogens other than COVID-19, was not apparent. This period coincided with the prolonged lockdown in England from January to April 2021; suggesting that public health measures may be able to modify a significant number of childhood deaths every year.

The main limitation of this work is precision of the estimates. Death in childhood is fortunately a rare event, with absolute mortality across the 2 years of around 27 per 100000 children per year. While we had adequate precision to identify an overall reduction in deaths, and the likely causal conditions (eg, infection) in which this occurred, we had less power to identify small, but still potentially important differences that might indicate which children were most affected by the broad social changes, and for which children the effects were less clear. Finally, like all work using routine data, case ascertainment may not be $100 \%$, although reporting to NCMD is a statutory requirement and cohort completeness has previously been reported as good, ${ }^{6}$ though we had missing data for some measures (eg, ethnicity).

Table 3 Number of deaths by year (starting April) stratified by provisional category of death with estimates of relative risk (RR) between years and proportion of excess deaths

\begin{tabular}{|c|c|c|c|c|c|}
\hline \multirow[b]{2}{*}{ Measure } & \multicolumn{5}{|c|}{ Comparison of deaths between 2019 and 2020 (April-March) } \\
\hline & 2019 & 2020 & Excess deaths & RR & $P$ value \\
\hline All deaths & 3423 & 3067 & $-356(-514$ to -198$)$ & 0.90 (0.85 to 0.94$)$ & $<0.001$ \\
\hline Malignancy & 258 & 262 & $4(-41$ to 49$)$ & 1.02 (0.86 to 1.21$)$ & 0.861 \\
\hline Preterm & 902 & 881 & $-21(-104$ to 62$)$ & 0.98 (0.89 to 1.07$)$ & 0.619 \\
\hline Intrapartum events & 166 & 191 & $25(-12$ to 62$)$ & 1.15 (0.93 to 1.42$)$ & 0.186 \\
\hline Infection & 164 & 81 & $-83(-114$ to -52$)$ & 0.49 (0.38 to 0.64$)$ & $<0.001$ \\
\hline Trauma & 164 & 195 & 31 (-6 to 68$)$ & 1.19 (0.97 to 1.46$)$ & 0.102 \\
\hline Road traffic accident & 54 & 62 & $8(-13$ to 29$)$ & $1.15(0.80-1.65)$ & 0.458 \\
\hline Drowning & 19 & 25 & $6(-7$ to 19$)$ & $1.32(0.72-2.39)$ & 0.367 \\
\hline Substance misuse & 20 & 10 & $-10(-21$ to 1$)$ & 0.50 (0.23 to 1.07$)$ & 0.074 \\
\hline Suicide & 109 & 120 & 11 (-19 to 41$)$ & 1.10 (0.85 to 1.43$)$ & 0.467 \\
\hline SUDIC & 432 & 416 & $-16(-73$ to 41$)$ & $0.96(0.84$ to 1.10$)$ & 0.583 \\
\hline Underlying medical condition & 1085 & 810 & $-275(-360$ to -190$)$ & 0.75 (0.68 to 0.82 ) & $<0.001$ \\
\hline
\end{tabular}

Numbers are frequency counts or RR plus $95 \% \mathrm{Cl}$ as appropriate.

Some deaths had insufficient information to assign a likely category of death.

RR derived from Negative Binomial Model (all alpha values approximating to 0 ).

SUDIC, sudden unexpected deaths in infancy or childhood. 
However, in contrast to emerging data on the mortality seen in adults, ${ }^{23}$ the restrictions and adaptations across England in 2020 to combat COVID-19 resulted in a dramatic reduction of childhood deaths, particularly in the younger children. The social restrictions during this time were broad, and included school and nursery closures ${ }^{24}$ with secondary impacts including reductions in air pollution and road traffic. ${ }^{25}$ In low/middleincome countries, a substantial indirect excess mortality is predicted $^{26}$ and across the world, measures of child mortality appear heterogeneous ${ }^{9}$ with the benefits of the social restrictions and the direct impact of COVID-19 likely to balance differently across different countries and pre-existing patterns of disease. However, in England, 2020 is likely to be the safest year on record for child deaths. ${ }^{2}$ While the NCMD has collated data since April 2019, crude mortality over time is well recorded through other statutory instruments, with ONS data showing little change in overall childhood mortality over the last 5 years. ${ }^{2}$ The coincidence of maximum lockdown regulations and the maximum reduction in mortality for younger children suggests that the lockdown regulations, including social distancing and reduction of social mixing, appeared most beneficial to younger children and perhaps to certain ethnic groups. While we know that children from some ethnic minority groups appear to be more likely to test positive ${ }^{14}$ and subsequently $\mathrm{die}^{27}$ of COVID19 , this pragmatic investigation of both the pandemic, and the responses to it, was unable to confirm a change in the profile of children dying in 2020-2021 from the preceding year. However, the reduction in all-cause mortality appeared greater for some ethnic minority groups and in areas of higher deprivation, groups recognised as having higher risk of death than others. ${ }^{132}{ }^{28}$ The measures put in place during the first year of the pandemic may have mitigated this patterning, although it should be noted that for most subgroups, mortality was reduced, and we had small absolute numbers making it difficult to show evidence of a real difference between any subgroups investigated here.

COVID-19 did contribute to overall childhood mortality; 70 children in this work died with a positive COVID-19 test and COVID-19 is likely to be the cause of death in around half of these. ${ }^{27}$ However, there was clear evidence that the reduction in mortality was seen in two key areas: those children with underlying diseases and those who died of infections, despite COVID19. The category of 'underlying diseases' was used to capture those children with an underlying condition able to explain their deaths, although the precipitant/contributory factor in many of these cases may also have been an infectious agent (eg, accelerating existing poor health in a child with complex needs). Consequently, it seems likely that reductions in infection underpin much of the effect seen; but whether this was through simple measures, like hand washing, or through substantial social changes, like the closure of nurseries and schools, is unclear.

Finally, we did not see clear increases in any single category of death. However, impacts may take time to show due to increasing numbers and precision, or through pathways which may take time to impact on mortality (eg, delayed diagnosis of malignancies or lack of mental health inpatient capacity). Possible increases in some categories of death were seen and we cannot exclude a small rise in suicide, ${ }^{29}{ }^{30}$ intrapartum ${ }^{31}$ or trauma deaths, ${ }^{32}$ although numbers remained small.

These data demonstrate that child deaths caused by (seasonal) infections are potentially substantially modifiable at population level. Impressive reductions in respiratory syncytial virus (RSV) and other respiratory virus infections in the winter months were reported in the first pandemic year. ${ }^{33}$ Indeed, while some pathogens appeared to rebound to normal seasonal levels after opening of schools and nurseries, and lifting of social distancing, ${ }^{34}$ RSV appeared to remain suppressed through the simple measures of mask wearing and enhanced hand washing. ${ }^{35}$ However, with the end of social distancing regulations in England, alongside the large cohort of immune-naïve children at risk, protected by the lockdown measures in 2020, the ongoing burden of RSV in young children is predicted to he high throughout the winter of $2021 / 2022 .^{36}$

\section{CONCLUSION}

What these data show is that, during 2020-2021, when multiple measures were introduced with the aim of reducing morbidity and mortality from COVID-19 in the adult population, there was an unexpected fall in overall child mortality in England, most marked in younger children and those with underlying health conditions and infectious disease other than COVID-19. The magnitude of this fall (around 10\%), including those children living in the most deprived conditions, a group for whom previous attempts to reduce excess mortality have generally been less successful, makes clear that we need to investigate what aspect of societal reorganisation and the restrictions faced by the whole population have had this effect. It is important that we learn from this effect, and identify which changes implemented over the last year would remain acceptable to protect the most vulnerable children in our society.

\section{Twitter Karen Luyt @KarenLuyt}

Acknowledgements We thank all Child Death Overview Panels (CDOPs) who submitted data for the purposes of this report and all child death review professionals for submitting data and providing additional information when requested. Parent and public involvement is at the heart of the NCMD programme. We are indebted to Charlotte Bevan (Sands - Stillbirth and Neonatal Death Charity), Therese McAlorum (Child Bereavement UK) and Jenny Ward (Lullaby Trust), who represent bereaved families on the NCMD programme steering group, for their advice and support with setting up the real-time child mortality surveillance system at the beginning of the COVID-19 pandemic, and their continued support and input at the regular managerial meetings during it; and Professor Chris Metcalfe (University of Bristol) for his statistical advice. We thank Dr Yvonne Silove (HQIP) for expert advice around data governance and data sharing for the linkage work; Public Health England's Field Service and National Child and Maternal Health Intelligence Network teams, for their collaboration in establishing the real-time surveillance system on child deaths potentially related to COVID-19 and ongoing support in the daily linkage with the SARS-CoV-2 test results; QES for rapidly developing and deploying the COVID module as part of the NCMD child death notification system; and CleverMed for their assistance in providing timely neonatal discharge summary data from BadgerNet to support the real-time child mortality surveillance system. We also thank the NCMD team for technical and administrative support.

Contributors DO participated in the study concept and design; contributed to acquisition, analysis and interpretation of data, and drafting and review of the manuscript; and saw and approved the final version. SS participated in the study design; contributed to data acquisition, linkage, analysis and interpretation of analysis, and drafting and review of the manuscript; and saw and approved the final version. TW participated in the study design; contributed to data acquisition, linkage, analysis and interpretation of data analyses, and reviewing the manuscript; and saw and approved the final version. PF participated in the study concept and design; contributed to acquisition and interpretation of data analysis, and reviewing the manuscript; and saw and approved the final version. KL obtained funding for this work; participated in the study concept and design; contributed to data acquisition and interpretation of data, and drafting and reviewing the manuscript; and saw and approved the final version. KL is responsible for the overall content as guarantor.

Funding The National Child Mortality Database (NCMD) programme, including this work, is funded by NHS-England and commissioned by the Healthcare Quality Improvement Partnership (HQIP) as part of the National Clinical Audit and Patient Outcomes Programme (NCAPOP).

Competing interests None declared.

\section{Patient consent for publication Not required.}

Ethics approval The National Child Mortality Database (NCMD) is set up as a part of statutory duty to record child mortality, with the purpose to investigate health issues in the child population in order to improve population health. The real-time 
surveillance of child mortality during the COVID-19 pandemic is delivered by the NCMD programme, with the purpose to investigate an outbreak/incident to help in disease control and prevention. This work is classified as Usual Practice in Public Health and Health Protection (http://www.hra-decisiontools.org.uk/research/docs/ definingresearchtable_oct2017-1.pdf) under the UK Policy Framework for Health and Social Care Research, and was reviewed by the Chair of the Central Bristol NHS Research Ethics Committee with confirmation that NHS ethical approval was not required.

Provenance and peer review Not commissioned; externally peer reviewed.

Data availability statement Data are available upon reasonable request. Aggregate data may be available on request to the corresponding author, and subject to approval by HQIP.

Open access This is an open access article distributed in accordance with the Creative Commons Attribution Non Commercial (CC BY-NC 4.0) license, which permits others to distribute, remix, adapt, build upon this work non-commercially, and license their derivative works on different terms, provided the original work is properly cited, appropriate credit is given, any changes made indicated, and the use is non-commercial. See: http://creativecommons.org/licenses/by-nc/4.0/.

\section{ORCID iDs}

Peter Fleming http://orcid.org/0000-0003-2521-5764

Karen Luyt http://orcid.org/0000-0002-9806-1092

\section{REFERENCES}

1 Deaths at home increased by a third in 2020, while deaths in hospitals fell except for COVID-19. Office of National Statistics (UK), 2021. Available: https://www.ons.gov.uk/ peoplepopulationandcommunity/birthsdeathsandmarriages/deaths/articles/deathsat homeincreasedbyathirdin2020whiledeathsinhospitalsfellexceptforcovid19/2021-0507

2 Child and infant mortality in England and Wales: 2019. Office of National Statistics (UK), 2021. Available: https://www.ons.gov.uk/peoplepopulationandcommunity/birt hsdeathsandmarriages/deaths/bulletins/childhoodinfantandperinatalmortalityinenglan dandwales/2019

3 Ladhani SN, Amin-Chowdhury Z, Davies HG, et al. COVID-19 in children: analysis of the first pandemic peak in England. Arch Dis Child 2020;105:1180-5.

4 Waite P, Moltrecht B, Mcelroy E. Report 02: Covid-19 worries, parent/carer stress and support needs, by child special educational needs and parent/carer work status: results from the first 5000 participants (the Co-SPACE study. Oxford, 2020.

5 Young Minds. Coronavirus: impact on young people with mental health needs. London: Young Minds (UK), 2020. https://youngminds.org.uk/media/3708/ coronavirus-report_march2020.pdf

6 Odd D, Sleap V, Appleby L. Child suicide rates during the COVID-19 pandemic in England: real-time surveillance. National child mortality database (UK), 2020. Available: https://www.ncmd.info/wp-content/uploads/2020/07/REF253-2020-\% OANCMD-Summary-Report-on-Child-Suicide-July-2020.pdf\%0A

7 Khalil A, von Dadelszen P, Draycott T, et al. Change in the incidence of stillbirth and preterm delivery during the COVID-19 pandemic. JAMA 2020;324:705.

8 Knight M, Bunch K, Vousden N, et al. Characteristics and outcomes of pregnant women admitted to hospital with confirmed SARS-CoV-2 infection in UK: national population based cohort study. BMJ 2020;369:m2107.

9 Islam N, Shkolnikov VM, Acosta RJ, et al. Excess deaths associated with covid-19 pandemic in 2020: age and sex disaggregated time series analysis in 29 high income countries. BMJ 2021:373:n1137.

10 Lanyon N, du Pré P, Thiruchelvam T, et al. Critical paediatric COVID-19: varied presentations but good outcomes. Arch Dis Child 2021;106:e10.

11 Moratto D, Giacomelli M, Chiarini M, et al. Immune response in children with COVID-19 is characterized by lower levels of T-cell activation than infected adults. Eur J Immunol 2020;50:1412-4.

12 Swann OV, Holden KA, Turtle L, et al. Clinical characteristics of children and young people admitted to hospital with covid-19 in United Kingdom: prospective multicentre observational cohort study. BMJ 2020;370:m3249.
13 Odd D, Stoianova S, Sleap V. Child mortality and social deprivation. National child mortality database (UK), 2021. Available: https://www.ncmd.info/2021/05/13/depreport-2021/

14 Odd D, Stoianova S, Williams T, et al. Child mortality in England during the COVID-19 pandemic. Arch Dis Child 2021;105:archdischild-2020-320899.

15 National child mortality database. Available: https://www.ncmd.info/ [Accessed 24 May 2020].

16 HM Government. Child death review: statutory and operational guidance (England). London: HM Government (UK), 2018. https://www.gov.uk/government/publications/ child-death-review-statutory-and-operational-guidance-england

17 Child Death Notifications Forms. HM government (UK). Available: https://www.gov.uk/ government/publications/child-death-reviews-forms-for-reporting-child-deaths

18 Sidebotham P, Fox J, Horwath J. Preventing childhood deaths. Department for children, schools and families (UK), 2008.

19 McLennan D, Noble S, Noble M. The English indices of deprivation 2019: technical report. Ministry of Housing, Communities and Local Government, 2019.

20 Joint agency response (JAR) to child deaths during COVID-19. National child mortality database (UK). Available: https://www.ncmd.info/2020/04/07/jar-covid-19/

21 Population estimates for the UK, England and Wales, Scotland and Northern Ireland: mid-2019. Office for national statistics (UK), 2020. Available: https:// www.ons.gov.uk/peoplepopulationandcommunity/populationandmig ration/populationestimates/bulletins/annualmidyearpopulationestimates/ mid2019estimates

22 Ethnicity and National Identity in England and Wales: 2011. Office for national statistics (UK), 2012. Available: https://www.ons.gov.uk/peoplepopulationandc ommunity/culturalidentity/ethnicity/articles/ethnicityandnationalidentityinenglandand wales/2012-12-11

23 Comparisons of all-cause mortality between European countries and regions: January to June 2020. Office of national statistics (UK), 2020. Available: https://www.ons.gov. uk/peoplepopulationandcommunity/birthsdeathsandmarriages/deaths/articles/comp arisonsofallcausemortalitybetweeneuropeancountriesandregions/januarytojune2020

24 Baker C, Kirk-Wade E, Brown J. Coronavirus: a history of English lockdown laws. HM government (UK). Available: https://commonslibrary.parliament.uk/research-briefings/ cbp-9068/

25 Brown L, Barnes J, Hayes E. Traffic-Related air pollution reduction at UK schools during the Covid-19 lockdown. Sci Total Environ 2021;780:146651.

26 Roberton T, Carter ED, Chou VB, et al. Early estimates of the indirect effects of the COVID-19 pandemic on maternal and child mortality in low-income and middleincome countries: a modelling study. Lancet Glob Health 2020;8:e901-8.

27 Smith C, Odd D, Harwood R. Deaths in children and young people in England following SARS-CoV-2 infection during the first pandemic year: a national study using linked mandatory child death reporting data. Res Sq 2021.

28 Williams T, Sleap V, Stoianova S. NCMD second annual report. National child Mortliaty database (UK), 2021. Available: https://www.ncmd.info/wp-content/uploads/2021/ 06/NCMD_2nd_Annual_Report_June-2021_web-FINAL.pdf

29 Buonsenso D, Roland D, De Rose C, et al. Schools closures during the COVID-19 pandemic: a catastrophic global situation. Pediatr Infect Dis J 2021;40:e146-50.

30 Odd D, Williams T, Appleby L. Child suicide rates during the COVID-19 pandemic in England. medRxiv2021.

31 Kc A, Gurung R, Kinney MV, et al. Effect of the COVID-19 pandemic response on intrapartum care, stillbirth, and neonatal mortality outcomes in Nepal: a prospective observational study. Lancet Glob Health 2020;8:e1273-81.

32 Sidpra J, Abomeli $D_{\text {, Hameed }}$, et al. Rise in the incidence of abusive head trauma during the COVID-19 pandemic. Arch Dis Child 2021;106:archdischild-2020-319872.

33 Williams TC, Sinha I, Barr IG, et al. Transmission of paediatric respiratory syncytial virus and influenza in the wake of the COVID-19 pandemic. Euro Surveill 2021;26.

34 Poole S, Brendish NJ, Tanner AR, et al. Physical distancing in schools for SARS-CoV-2 and the resurgence of rhinovirus. Lancet Respir Med 2020;8:e92-3.

35 Di Mattia G, Nenna R, Mancino E, et al. During the COVID-19 pandemic where has respiratory syncytial virus gone? Pediatr Pulmonol 2021;56:3106-9.

36 Respiratory syncytial virus 2021 preparedness. NHS England, 2021. Available: https:// www.england.nhs.uk/publication/respiratory-syncytial-virus-2021/ 